\title{
Effects of drilling depth on seedling growth of seven dryland pasture species
}

R.F. WOODMAN, R.J. DONEY and B.E. ALLAN Tara Hills Research Station, Ministry of Agriculture and Fisheries, O marama

\begin{abstract}
The effects of sowing depth on the seedling growth of three dryland pasture grasses and five legumes from an on-farm trial in the Hakataramea 'Valley, South Canterbury was examined. The drill was set to sow seed at depths of $10 \mathrm{~mm}, 20 \mathrm{~mm}$, or $30 \mathrm{~mm}$ depending upon species, but in practice a wide range of drilling depths occurred. Seedling growth was highly correlated with sowing depth for the majority of species. The level of dependence of seedling growth upon sowing depth for the species examined was as follows: Tetra alsike $>>$ Cascade birdsfoot trefoil $=$ Kara cocksfoot $>$ Hakari brome = Dryland birdsfoot trefoil $=$ Redquin red clover $>>W L$ 320 lucerne $=$ Maru phalaris. In general, seedling growth was good from sowing depths of less than $12.5 \mathrm{~mm}$ and extremely poor from depths greater than $25 \mathrm{~mm}$. A prediction of the relationship for these species on the basis of seed weight was not possible.
\end{abstract}

Keywords sowing depth, pasture species, dryland species, seedling growth, hypocotyl length, epicotyl length

\section{Introduction}

Good seedling establishment is vital to the development of a successful and productive pasture. Modern technology such as improved drills, weed control and seed coating has greatly improved establishment, but despite early reports of sowing depth effects on seedling emergence (Beveridge \& Wilsie 1959; Kalton et al. 1959), and more recent work on tall fescue and ryegrass (Brock 1973) and red clover and ryegrass (Campbell et al. 1983; Campbell et al. 1985; Campbell 1985a, b), the importance of sowing depth is often overlooked.

The optimum seedling depth for many grasses, clovers, as well as birdsfoot trefoil and lucerne is recognised as 6 to $12.5 \mathrm{~mm}$ (Moore 1943; Chapman et al. 1990). However, in dry environments a dilemma exists between sowing shallow to ensure emergence and sowing deeper to ensure access to moisture. Many of the new species and cultivars promoted for dry environments are slow to establish and seed is generally expensive. Establishment failures with these 'unproven' species can, regardless of the reasons, soon create farmer scepticism.

Studies aimed at quantifying seed depth effects for new dryland species are scarce. An on-farm trial in the Hakataramea Valley, South Canterbury, was established to examine the role of new species for fertile but drought-prone soils. Observations 3 weeks after sowing revealed differences in seedling numbers and growth between species, and in some instances within species, apparently because of variations in drilling depth.

Measurements were made to determine the effects of sowing depth on the growth of seven dryland species using epicotyl and hypocotyl length as an indicator of seed placement depth.

\section{Methods and materials}

\section{Experimental area}

The trial site was located at Belfield Station, Hakataramea Valley, on a Struan-Oturehua, southern yellow-grey earth soil (mean annual rainfall 450-mm-soil-pH-5-7; -altitude-250.m.asl). Glyphosate (Roundup) herbicide was applied at a rate of 3 litres/ha (360 g/l active ingredient) with Pulse penetrant and surfactant $(100 \mathrm{ml} / 1001$ water $)$ in October 1989 and the site was 'maxitilled' in early January 1990. Drought-tolerant grass and legume species were cross-drilled within a fully randomised block design using 4 replicates. The total drilled area was 17.5 ha. The area received an initial topdressing of $1000 \mathrm{~kg} / \mathrm{ha}$ lime and sulphur superphosphate was drilled with the seed at a rate of $200 \mathrm{~kg} / \mathrm{ha}$.

\section{Drilling and environmental conditions}

The trial site was drilled at the end of January 1990 using a Duncan 750 Tillseeder at a speed of 6-8 $\mathrm{km} / \mathrm{h}$. Three seed placement depth settings were used: $10 \mathrm{~mm}$ for birdsfoot trefoil cv. Dryland and Cascade; $20 \mathrm{~mm}$ for red clover $\mathrm{cv}$. 'Grasslands Pawera' and Redquin, alsike clover (Tetra), lucerne (WL320) and 'Grasslands Maru' phalaris; and 30 $\mathrm{mm}$ for Secale montanum cv. Black Mountain, 'Grasslands Hakari' mountain brome, 'Grasslands Kara' cocksfoot, Mandan wheatgrass, 'Grasslands Tiki' smooth bromegrdss and tall oat grass. 
Table 1 Seed weights, sowing rates, viable seeds sown and seedling numbers 5 weeks after sowing.

\begin{tabular}{|c|c|c|c|c|c|}
\hline Species & $\begin{array}{l}\text { Seed weight } \\
(\mathrm{g} / 1000 \text { seeds })\end{array}$ & $\begin{array}{l}\text { Sowing rate } \\
\mathbf{( k g / h a )}\end{array}$ & $\begin{array}{l}\text { Viable seeds } \\
\text { sown } / \mathrm{m}\end{array}$ & $\begin{array}{l}\text { Seedling, } \\
\text { numbers/m }\end{array}$ & $\begin{array}{l}\% \text { Seedlings } \\
\text { from viable } \\
\text { seed sown }\end{array}$ \\
\hline \multicolumn{6}{|l|}{ Trifolium pratense } \\
\hline $\begin{array}{l}\text { Pawera red clover } \\
\text { Trifolium pratense }\end{array}$ & 3.8 & 5.5 & 128 & 2 & 1.6 \\
\hline $\begin{array}{l}\text { Redquin red clover } \\
\text { Trifolium hybridum }\end{array}$ & 1.8 & 5.5 & 275 & 6 & 2.2 \\
\hline $\begin{array}{l}\text { Tetra alsike } \\
\text { Medicago sativa }\end{array}$ & 1.3 & 5.5 & 381 & 8 & 2.1 \\
\hline $\begin{array}{l}\text { WL320 lucerne } \\
\text { Lotus corniculatus }\end{array}$ & 2.6 & 6.0 & 198 & 40 & 20.0 \\
\hline $\begin{array}{l}\text { Cascade birdsfoot trefoil } \\
\text { Lotus corniculatus }\end{array}$ & 1.25 & 5.0 & 388 & 38 & 9.8 \\
\hline $\begin{array}{l}\text { Dryland birdsfoot trefoil } \\
\text { Secale montanum }\end{array}$ & 1.25 & 5.0 & 380 & 40 & 10.5 \\
\hline $\begin{array}{l}\text { Black Mountain rye } \\
\text { Bromus sitchensis }\end{array}$ & 11.7 & 35.0 & 251 & 44 & 17.5 \\
\hline $\begin{array}{l}\text { Hakari mountain brome } \\
\text { Bromus inermis }\end{array}$ & 9.4 & 27.0 & 230 & 88 & 38.0 \\
\hline $\begin{array}{l}\text { Tiki smooth brome } \\
\text { Elytrigia intermedia }\end{array}$ & 4.1 & 11.0 & 201 & 28 & 13.9 \\
\hline $\begin{array}{l}\text { Mandan wheatgrass } \\
\text { Phalaris aquatica }\end{array}$ & 5.4 & 33.0 & 565 & 112 & 19.8 \\
\hline $\begin{array}{l}\text { Maru phalaris } \\
\text { Dactylis glomerata }\end{array}$ & 1.75 & 8.0 & 367 & 132 & 37.0 \\
\hline $\begin{array}{l}\text { Kara cocksfoot } \\
\text { Arrhenatherum elatius }\end{array}$ & 0.75 & 10.0 & 1,053 & 48 & 4.6 \\
\hline $\begin{array}{l}\text { tall oat grass } \\
\text { Lolium perenne }\end{array}$ & 2.6 & 7.0 & 210 & 32 & 15.2 \\
\hline local ecotype ryegrass & 1.9 & 17.0 & 877 & 172 & 19.6 \\
\hline
\end{tabular}

Botanical names, seed weight, sowing rate and viable seeds sown for each species are shown in Table 1.

At drilling, soil conditions were dry. Eleven mm rain fell within 3 days of drilling and $19.5 \mathrm{~mm} 4$ days later, followed by mild " temperatures and then a further $19 \mathrm{~mm}$ of rain within the following 8 days.

\section{Measurements}

Five weeks after drilling, seedlings were counted using 20 random placements of a $0.25 \mathrm{~m}^{2}$ quadrat per replicate. Where within-species differences in seedling numbers were large, samples of poor and vigorous drill rows were removed from each replicate using the sampling frame described by Kaviani et al. (1985). In the laboratory, seedlings were removed individually from the row samples by hand and excess soil removed from the root systems. The epicotyl length of grasses, hypocotyl length of legumes, shoot height (measured from shoot base to tip), leaf number, length of longest root (measured from shoot base to root tip) and shoot fresh weight were recorded. To obtain dry weights plant shoots were classed according to epicotyl and hypocotyl lengths, then oven dried at $60^{\circ} \mathrm{C}$. For the grasses, the divisions were within $2 \mathrm{~mm}$ epicotyl lengths, and for the legumes, the divisions were within $1 \mathrm{~mm}$ hypocotyl lengths.

The relationships between depth of seed placement (i.e. epicotyl/hypocotyl length) and other parameters were best fitted by linear regression analysis.

\section{Results}

Table 1 presents seedling establishment numbers 5 weeks after sowing. Seedling establishment as a percentage of viable seeds sown varied widely between species, from $38 \%$ with Hakari down to $1.6 \%$ with red clover.

Regressions of sowing depth (as represented by hypocotyl and epicotyl lengths) with shoot height, leaf numbers, root length and shoot fresh weight were not significant. However, over the range of depths, the effect of sowing depth on seedling growth (as represented by shoot dry weight) was significant for the majority of grasses (Figure 1), and legumes

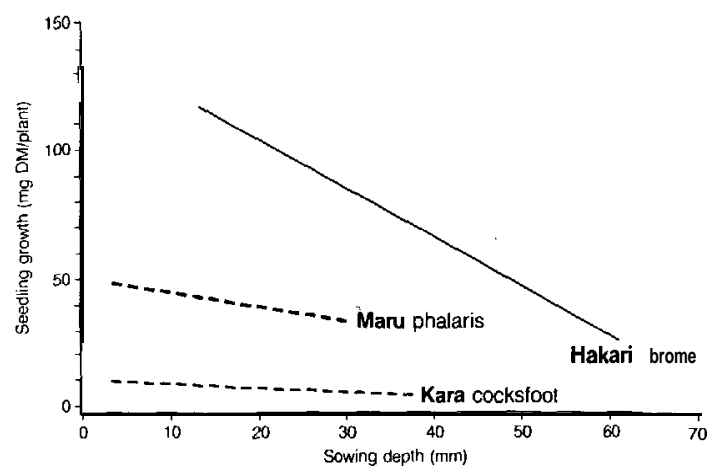

Figure 1 The relationships between sowing depth and seedling growth at 5 weeks of three dryland species. 


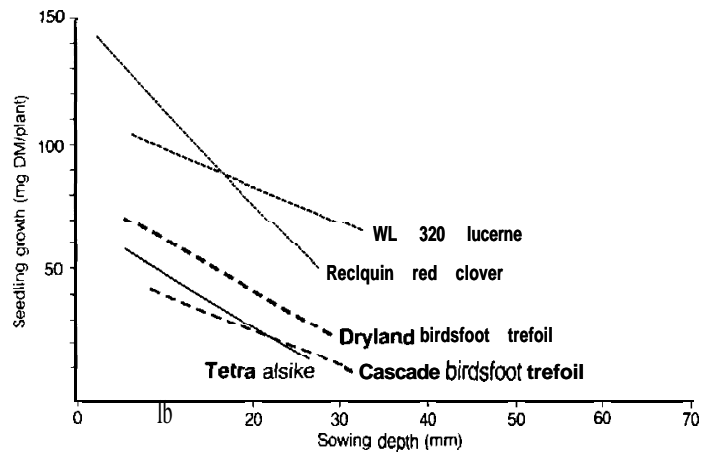

Figure 2 The relationships between sowing depth and seedling growth at 5 weeks of five dryland legumes.

(Figure 2) sampled. Seedling growth declined as sowing depth increased.

There were differences in the relationships between sowing depth and seedling growth for the selected species (Table 2). In the grasses, Kara cocksfoot formed the strongest negative relationship $(\mathrm{P}<0.01)$, Hakari brome showed a weaker relationship $(\mathrm{P}<0.05)$, whilst Maru phalaris seedling growth was not significantly affected by seedling depth over the range tested. The growth of Tetra alsike and Cascade birdsfoot trefoil seedlings was strongly associated with sowing depth $(\mathrm{P}<0.001$ and 0.01 respectively). Redquin red clover and Dryland birdsfoot trefoil showed a moderate association $(\mathrm{P}<0.05)$, while lucerne was not significantly affected.

Increasing the seedling depth from 6 to $31 \mathrm{~mm}$ decreased seedling growth as follows: Tetra alsike $(100 \%)$, Cascade birdsfoot trefoil $(82 \%)$, Redquin red clover $(\mathbf{7 5 \%})$, Dryland birdsfoot trefoil $(\mathbf{7 4 \%})$, Kara cocksfoot (48\%) and Hakari brome (36\%).

There were large differences in seed weights within the grasses and legumes (Table 1). The effects of seed weight on the relationship between sowing depth and seedling growth was examined. Hakari brome, with a heavy seed, was affected by sowing depth, whereas Maru phalaris, with a lighter seed, showed no effect (Table 2). However, the seedling growth of both Redquin red clover and Dryland birdsfoot trefoil was similarly affected by sowing depth, despite the larger seed weight of Redquin red clover relative to Dryland birdsfoot trefoil.

There was no evidence of invertebrate pest damage to any of the pasture species examined.

\section{Discussion}

The epicotyl length of grasses and hypocotyl length of legumes appears to be a satisfactory method of determining seed sowing depth, even in plants at 5 weeks of age. The method can be used both in the laboratory and field situations.

The optimum sowing depth for most pasture species is generally accepted to be around $12.5 \mathrm{~mm}$. Sowing too deeply can seriously reduce seedling emergence and growth (King \& Bladen 1989), although in dry conditions slightly deeper sowing may improve emergence by allowing better access to moisture.

Emergence is delayed from deeper drilling (Campbell 1985a). Deeper sown seedlings are likely to use more of their food reserves in reaching the surface than those sown at shallower depths and as a consequence are slower to develop and are probably more susceptible to establishment failure.

Kara cocksfoot was highly sensitive to sowing depth, supporting recent work on cocksfoot by King and Bladen (1989). Cocksfoot generally has poor seedling growth, for example compare the range in shoot dry weight for Kara cocksfoot to that for Hakari brome in Figure 1. Because of this, and its sensitivity to sowing depth, every effort should be made to ensure Kara cocksfoot is sown as shallow as possible, certainly no deeper than $12.5 \mathrm{~mm}$. Like Kara cocksfoot, Hakari brome seedling growth was significantly affected by sowing depth, but the inherent vigour of this cultivar means it can tolerate deeper sowing (i.e., 12-30 mm).

When sown at the same range of depths as the legumes, the growth of Maru phalaris was acceptable at sowing depths that seriously reduced the growth of most legumes. Lucerne was the only legume whose seedlings growth was not significantly affected by the sowing depths.

Seedling growth of Tetra alsike was particularly sensitive to sowing depth, as recognised by Moore (1943) who recommended a sowing depth of between 6 and $12 \mathrm{~mm}$. Red clover also showed sensitivity to sowing depth, which is contrary to work by Campbell (1985b) which reported very little response in red clover to direct-drilled depths at 13,26 and $39 \mathrm{~mm}$. However, the winged coulter used by Campbell may have created more favourable conditions for optimum germination and emergence. The growth of birdsfoot trefoil seedlings (notably Cascade) was highly sensitive to sowing depth. It is noteworthy that Dryland birdsfoot trefoil showed greater seedling growth than Cascade and was also less affected by sowing depth. However, for birdsfoot trefoil in general, seeds should not be planted deeper than 12.5 $\mathrm{mm}$, as was recently recommended by Chapman $e t$ al. (1990).

Table 2 Relationships between sowing depth and shoot dry matter for some dryland grasses and legumes 5 weeks after drilling. Shoot dry weight/plant $=\mathrm{m} \times$ sowing depth $+\mathrm{c}$. $\mathrm{n}=$ number of observations.

\begin{tabular}{|c|c|c|c|c|c|}
\hline & Cultivar & $\mathrm{n}$ & $\mathrm{m}$ & c & Significance \\
\hline Cocksfoot & Kara & 27 & -0.1716 & 10. 127 & 18 \\
\hline Brome & Hakari & 19 & $=1.885$ & 142.2 & $*$ \\
\hline Phalaris & Maru & 13 & -0.554 & 50.42 & NS \\
\hline \multicolumn{6}{|l|}{ Lotus } \\
\hline \multirow[t]{2}{*}{ corniculatus } & Cascade & 20 & -1.4305 & 53.25 & ** \\
\hline & Dryland & 22 & -2.013 & 80.8 & * \\
\hline Red clover & Redquin & 23 & -3.780 & 150.6 & - \\
\hline Alsike & Tetra & 21 & -2.120 & 68.60 & - 88 \\
\hline Lucerne & WL320 & 25 & 1.480 & 112.9 & NS \\
\hline
\end{tabular}


The fact that seed weight and seedling growth were unrelated in this study supports previous reports from Beveridge \& Wilsie (1959). Clearly it cannot be assumed that the heavier the seed, the better the seedling growth.

Despite the attempts made to control sowing depths at 10, 20 and $30 \mathrm{~mm}$, in practice a wide range of drilling depths occurred. For example, the birdsfoot trefoils, where the drill was set to sow at 10 $\mathrm{mm}$, were sown at least as deep as $30 \mathrm{~mm}$ (Figure 2). Similarly, Hakari brome set for $30 \mathrm{~mm}$, was sown as deep as $60 \mathrm{~mm}$ (Figure 1). This suggests the uneven surface and variable structure of the soil in this tria resulted in inaccurate seed depth placement. This limitation of the Tillseeder highlights the need for drilling equipment that can consistently place seed at the optimum depth despite difficult and variable soil physical conditions. In the south, this challenge is being addressed in a partnership between MAF Technology South and the NZAEI to develop effective low-cost over-drilling technology for the establishment of new pasture cultivars.

These results quantify the effects of excessive sowing depth on seedlings growth and in doing so enhance the current understanding of problems associated with the establishment of dryland species.

\section{Conclusions}

The importance of shallow planting to obtain optimum seedling numbers and growth, irrespective of seed weight, cannot be stressed too strongly. Sowing at a depth of less than $13 \mathrm{~mm}$ resulted in good seedling growth for all the species considered. Sowing at a depth in excess of $25 \mathrm{~mm}$ drastically inhibited seedling growth. Epicotyl length in grasses and hypocotyl length in legumes appeared to be a sucesssful method of determining actual seed sowing depth.

\section{ACKNOWLEDGEMENTS}

Mr W. Fraser and Ms Ankersmit for technical assistance Dr K. Dodds for statistical analysis, Dr W.L. Lowther for helpful suggestions and $\mathrm{Mr} \mathrm{J}$. McKenzie for providing the on-farm trial site.

\section{REFERENCES}

Beveridge, J.L.; Wilsie, C.P. 1959. Influence of depth of planting, seed size and variety on emergence and seedling vigour in Alfalfa. Agronomy journal st: 731-734.

Brock, J.L. 1973. Effect of sowing depth and post-sowing compaction on the establishment of tall fescue varieties. NZ journal of experimental agriculture I: $1-14$.

Campbell, B.D.; Cosgrove, G.P.; Harris, W. 1983. Why overdrilling red clover in Manawatu lowland failed. Proceedings of the NZ Grassland Association 44: 156-163.

Campbell, B.D.; McDonald, J.H.; Baker, C.J. 1985. A mechanism to regulate winged coulter depth and overdrilled seed spacing in field experiments. $N Z$ journal of experimental agriculture 13: 175-179.

Campbell, B.D. 1985a. Winged coulter depth effects on overdrilled red clover seedling emergence. $N Z$ journal of agriculture science 28: 7-17.

Campbell, B.D. 1985b. Planting depth effects on overdrilled seedling survival in summer. $N Z$ journal of experimental agriculture 13: 103-109.

Chapman, H.M.; Lowther, W.L.; Trainor, K.D. 1990. Some factors limiting the success of Lotus corniculatus in hill and high country. Procedings of the NZ Grasslands Association 5I: 147-150.

Kalton, R.R.; Delong, R.A.; McLeod, D.S. 1959. Cultural factors in seedling vigour of smooth brome grass and other forage species. Iowa State journal of science 34: 47-80.

Kaviani, N.; Gibbs, R.N.; Horrell, R.F. 1985. Seed placement measuring technique for direct drilling machines - a note. NZ journal of experimental agriculture Vol. 13: 191-194.

King, J.R.; Bladen, C. 1989. The effect of depth of seedling and soil crusting on germination and establishment of seven pasture grass species. Proceedings of the XVI International Grassland Congress, Nice, France Vol. I: $551-552$.

Moore, R.P. 1943. Seedling emergence of small seeded legumes and grasses. Journal of American Society of Agronomy 35: 370-381.

Murphy, R.P.; Arny, A.C. 1939. The emergence of grass and legume seedlings planted at different depths in five soil types. Journal of American Society of Agronomy 31: $17-18$ 